\title{
Effect of the wrapping of experimentally induced ischemic colonic anastomoses with the amniotic membrane on anastomosis safety in rats.
}

\section{Ratlarda deneysel oluşturulan iskemik kolon anastomozlarının amniyotik membran ile sarılmasının anastomoz güvenliğine etkisi}

\author{
Sinan Soylu ${ }^{1}$, Zeynep Deniz Sahin Inan²
}

Department Of General Surgery, Cumhuriyet University School of Medicine, Sivas, Turkey

${ }^{2}$ Cumhuriyet University, Faculty of Medicine, Department of Histology and Embryology, Sivas, Turkey

Corresponding author: Sinan Soylu, MD., Department Of General Surgery, Cumhuriyet University School of Medicine, Sivas, Turkey

E-mail: soylu.sinan@hotmail.com

Received/Accepted: September 17,2018/September 18, 2018

Conflict of interest: There is not a conflict of interest.

\section{SUMMARY}

Objective: Colonic anastomotic leakage represents a complication with high mortality and morbidity. In the present study, it was aimed to examine the effect of the amniotic membrane on the healing of ischemic colonic anastomosis.

Method: 25 pregnant Wistar albino rats aged 19-21 days were randomly divided into 5 groups. With midline laparotomy, pregnancies were terminated, and fresh amniotic membranes were obtained. In Group 1 Sham (S), no procedure except for laparotomy was performed. In Group 2 of colonic anastomosis (A), the descending colon was completely transected and anastomosed. In Group 3 of amniotic anastomosis (AA), the anastomosis line was fixed by being wrapped with the fresh amniotic membrane. In Group 4 of colonic ischemic anastomosis (IA), the marginal arteries were ligated after descending colon transection. Ischemia was induced, and anastomosis was performed. In Group 5 of colonic ischemic anastomosis wrapped with the amniotic membrane (AIA), after ischemic colonic anastomosis was performed, the anastomosis line was fixed by being wrapped with the amniotic membrane. On the postoperative 7th day, rats were sacrificed, and their anastomotic bursting pressures were measured. For histological examination, the colon segment containing the anastomosis line was removed. Hematoxylin-eosin and Van Gieson trichrome stained specimens were histologically evaluated and scored according to the Ehrlich-Hunt model.

Results: Anastomotic bursting pressures were measured in group S as the highest, in AA, AIA, A in a decreasing order and in group IA as the lowest. The difference between groups $S$ and AA was statistically insignificant in the paired comparison of groups according to their bursting pressure values $(\mathrm{p}=0.222)$. When the other pairs were compared, the difference between the groups was calculated as significant ( $\mathrm{p}<0.05)$. According to the Ehrlich-Hunt model, the total score was the highest in AIA group, decreased in AA, IA, A groups in a decreasing order, and was the lowest in group $\mathrm{S}$. A paired comparison for total scores between the groups was statistically insignificant between groups $\mathrm{S}$ and $\mathrm{A}$ $(\mathrm{p}=0.222)$. Other paired comparisons were statistically significant $(\mathrm{p}<0.05)$.

Conclusions: Wrapping the colon anastomosis line with the amniotic membrane gave positive results both in the ischemic colon as well as in the non-ischemic colon in terms of bursting pressure and histological anastomosis safety.

Keywords: Ischemic colon, Anastomosis safety, Amniotic membrane 


\section{ÖZET}

Amaç: Kolon anastomoz kaçağı yüksek mortalite ve morbidite ile seyreden bir komplikasyondur. Bu çalışmada iskemik kolon anostomoz iyileşmesine amniyon zarının etkisini araştırmayı amaçladık.

Yöntem: 25 adet vistar albino cinsi 19-21 günlük gebe rat rastgele 5 gruba ayrıldı. Orta hattan yapılan laparatomi ile gebelikler sonlandırıldı ve taze amniyon zarı elde edildi. Grup 1Sham(S); laparatomi dișında işlem yapılmadı. Grup 2 kolon anastomozu(A) ; inen kolon tam transekte edilerek anastomoz uyguland1. Grup3 amniyonlu anastomoz (AA); anastomoz hattına taze amniyon zarı sarılarak tesbit edildi. Grup 4 kolon iskemik anastomoz(İA); inen kolon transeksiyonu sonrası marjinal arterler bağlandı. İskemi oluşturuldu. Anastomoz yapıldı. Grup 5 amniyon zarı sarılmış kolon iskemik anastomoz(AİA); iskemik kolon anastomozu yapıldıktan sonra anastomoz hattına amniyon zarı sarılarak tesbit edildi. Postoperatif 7 günde ratlar sakrifiye edilerek anastomoz patlama basınçları ölçüldü. Histolojik inceleme için anastomoz hattını içeren kolon segmenti çıkarıldı. Hemotoksilen eozin ve Van gieson trichtome boyalı örnekler histolojik olarak değerlendirilerek Ehrlich-Hunt modeline göre skorland1.

Bulgular: Anastomoz patlama basıncı değerleri en yüksek S grubunda, azalan sıra ile AA, AİA, A ve en düşük İA grubunda ölçüldü. Patlama basıncı değerlerine göre grupların ikili karşılaştırmasında S ile AA grupları arası fark istatiksel olarak anlamsız olarak hesaplandı $(\mathrm{p}=0,222)$. Diğer ikili karşılatırıldığında gruplar arası fark anlamlı olarak hesaplandı $(\mathrm{p}<0.05)$. Grupların Ehrlich-Hunt modeline göre toplam skor en yüksek AİA ve azalan sıra ile AA, İA, A ve en düşük S grubunda olduğu bulundu. Gruplar arası toplam skorlar için ikili karşılaştırmada S ile A gruplar arası istatiksel olarak anlamsız olarak hesaplandı( $\mathrm{p}=0,222)$. Diğer ikili karşılaştırmalar istatiksel olarak anlamlı olarak hesapland1 $(\mathrm{p}<0.05)$.

Sonuç: Kolon anastomoz hattına amniyon zarı sarılması hem iskemik kolonda hemde iskemik olmayan kolonda patlama basıncı ve histopatolojik olarak anastomoz güvenliği açısından olumlu sonuçlar vermiştir.

Anahtar sözcükler: İskemik kolon, Anastomoz güvenliği, Amnion zarı

\section{INTRODUCTION}

Anastomotic leakage (AL) remains the most significant complication after colorectal surgery. Anastomotic leakage occurs in the range from $2.4 \%$ to $69 \%{ }^{1}$. This complication is still a serious problem, which increases the morbidity and mortality rates ${ }^{2}$. A lot of different factors can disrupt colon anastomosis healing. The excessive or insufficient mobilization of colonic segments and tight suturing can lead to the impairment of tissue perfusion and oxygenation. On the other hand, particularly in patients with colonic perfusion disorders and/or ischemic anastomotic edges resulting from an insufficient surgical technique, it may prevent safe anastomosis ${ }^{3,4}$.

A lot of studies have been carried out to find materials and surgical techniques for the purpose of protecting high-risk gastrointestinal anastomosis $^{5-7}$. Peritoneum, collagen, and synthetic materials (polymers) and sealants have been investigated in previous studies for the purpose of protecting anastomosis and preventing $\mathrm{AL}^{5-9}$. Most of these studies are animal studies, and satisfactory results have not been obtained. Therefore, they have not been widely used in clinical practice ${ }^{10-14}$. Synthetic materials are available, but the use of these products causes additional complications. Therefore, the benefits are still controversial.

There is a growing interest in the use of human amniotic membrane (HAM) as a biologic dressing for the purpose of promoting the wound healing process. The amniotic membrane represents the innermost of three fetal membrane layers, including an avascular stromal matrix, thick basement membrane and a single layer of the epithelium $^{15}$. Basement membrane components, growth factors, and proteinase inhibitors are included in the amniotic membrane ${ }^{15,16}$. Studies have shown that the HAM has antibacterial properties and low immunogenicity and is also capable of promoting epithelization and wound healing, preventing inflammation and scarring, and regulating angiogenesis ${ }^{18-21}$. These effects are some advantages of HAM, which have been expected by the researchers to investigate the efficiency of the mentioned biomaterial in colonic $\operatorname{anastomoses}^{22,23}$.

In the present study, it was aimed to investigate the effect of the amniotic membrane on the safety of anastomosis in high-risk ischemic conditions. 


\section{MATERIAL AND METHODS}

Twenty-five pregnant Wistar-Albino rats with the weight ranging from 200 to $250 \mathrm{~g}$ (mean weight of $225 \mathrm{~g}$ ) were included in the study. The rats were supplied by Cumhuriyet University School of Medicine Animal Laboratory Sivas, Turkey. Approval of the study protocol was received from Cumhuriyet University Institutional Ethics Committee for Animal Experiments (SivasTurkey, date 24/06/2015 code: 65202830050.04.04/51). All of the examinations were performed in conformity with the 1996 National Academy of Science's Guide for the Care and Use of Laboratory Animals.

\section{Study design}

The animals were kept in cages under the room temperature of 21 to $23^{\circ} \mathrm{C}$ with a $12 / 12$-hour light/dark cycle, and standard feed and water ad libitum were given to them. Simple randomization was utilized in the present study. Pregnant rats aged 19-21 days were randomly divided into 5 groups. The rats which reached the 19th day of pregnancy were anesthetized by the subcutaneous injection of ketamine $\left(90 \mathrm{mg} / \mathrm{kg}\right.$; Ketalar ${ }^{\circledR}$; ParkeDavis, Istanbul, Turkey) and xylazine $(3 \mathrm{mg} / \mathrm{kg}$ Rhompun ${ }^{\circledR}$; Bayer, Istanbul, Turkey). With midline laparotomy, pregnancies were terminated, and fresh amniotic membranes were obtained. In Group 1Sham (S), no procedure except for laparotomy was performed. In Group 2 of colonic anastomosis (A), the descending colon was completely transected and anastomosed. In Group 3 of amniotic anastomosis (AA), the anastomosis line was fixed by being wrapped with the fresh amniotic membrane. In Group 4 of colonic ischemic anastomosis (IA), the marginal arteries were ligated after descending colon transection. Ischemia was induced, and anastomosis was performed. In Group 5 of colonic ischemic anastomosis wrapped with the amniotic membrane (AIA), after ischemic colonic anastomosis was performed, the amniotic membrane was fixed around the anastomosis line. On the postoperative 7 th day, rats were sacrificed, and their anastomotic bursting pressures were measured.

Anastomotic bursting pressure

A 2/0 silk suture was used to tie the distal ends of resected anastomotic colon segments. A catheter was positioned into the lumen at the proximal end with the other end of the catheter attached to a transducer and an air pump. A setup required to measure the intraluminal pressure in millimeters of mercury $(\mathrm{mmHg})$, and this was achieved. The anastomotic colonic segment was put into a bowl filled with water. The air was blown into the colonic lumen at a $2 \mathrm{ml} / \mathrm{min}$ insufflation rate. The first air leakage from the anastomotic line was documented as the anastomotic bursting pressure.

\section{Histopathological Examination}

For histological examination, the colon segment including the anastomosis line was removed. Hematoxylin-eosin and Van Gieson trichrome stained specimens were evaluated histologically and scored in accordance with the Ehrlich-Hunt model $^{24}$ (Table 1). The tissue was assessed with regard to the quantity of fibroblasts, neovascularization level, and collagen content. The same pathologist, blinded to the study groups, conducted the pathologic evaluation. 


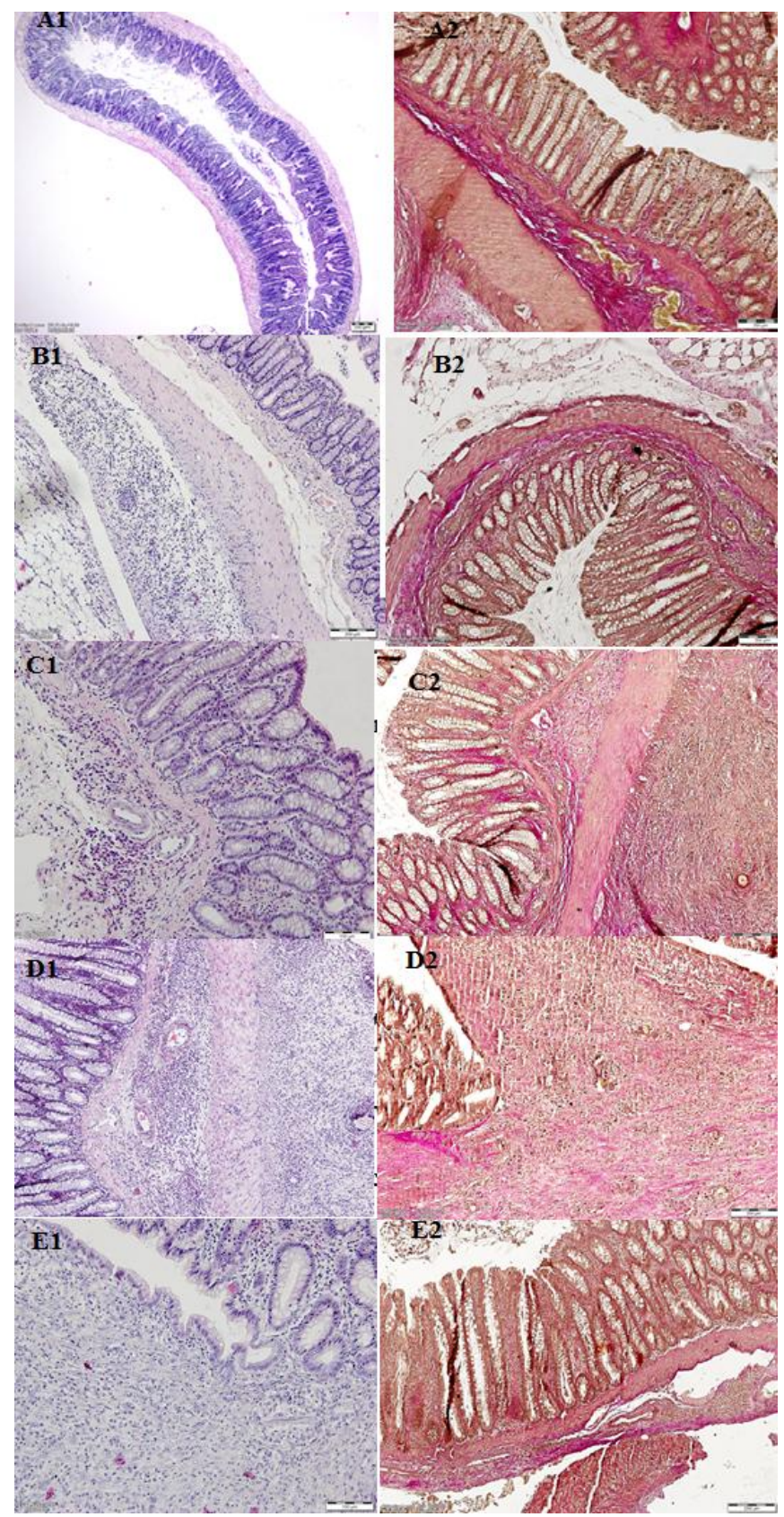

Figure 1. Hematoxylin-eosin (1) and Van Gieson Trichrome (2) stained preparates of the groups.

A1: Control group (4x, H\&E). Tunica mucosa, tunica submucosa, muscularis mucosa layers are observed in the control group, to which no application was performed.

A2: Control group (20x, VAN GIESON TRICHROME).

B1: Non-ischemic anastomosis (20x, H\&E): The Tunica mucosa epithelium shows continuity. Lieberkühn crypts are regular, there are lymphocytes, plasma cells, mast cells, eosinophils and histiocytes in the lamina propria, as in the control group. The tunica muscularis layer is regular. The tunica submucosa contains cells, blood vessels, lymphatics and nerve extremities as in the lamina propria. The tunica submucosa shows normal loose connective tissue properties.

B2: Non-ischemic anastomosis (20x, VAN GIESON TRICHROME)

C1: Amniotic anastomosis group (20x, H\&E): The tunica mucosa is composed of regular Lieberkühn crypts and surrounding epithelial cells. The lamina propria contains dense lymphocytes, plasma cells, eosinophils. The tunica muscularis layer is as regular as possible. Intensive cell infiltration, intense blood vessel areas can be observed in the tunica submucosa. The tunica muscularis layer shows normal localization. In the tunica serosa, intense inflammatory cell infiltration and blood vessels are observed in the loose connective tissue layer.

C2: Amniotic anastomosis group (20x, VAN GIESON TRICHROME).

D1: Ischemic anastomosis group (20x, H\&E). Peeling in the superficial epithelium of the tunica mucosa, and the disruption of the structure of Lieberkühn crypts and intense inflammatory cells are observed in the lamina propria.

D2: Ischemic anastomosis group (20x, VAN GIESON TRICHROME)

E1: Ischemic amnion group (20x H\&E). The regular tunica mucosa layer and the lamina propria which is located around it are observed. The lamina propria contains capillaries and inflammatory cells in general. In the tunica submucosa, very intense blood vessel areas and inflammatory cells are noteworthy. The tunica muscularis layer is inflammatory between the muscle cells while it is partly regular.

E2: Ischemic amnion anastomosis group (20x, VAN GIESON TRICHROME). 
Statistical Analysis

All data were recorded in SPSS for Windows 23.0 package programme (IBM Japan, Tokyo, Japan) and were expressed as mean \pm standard deviation. The normality test of inflammatory cells, fibroblasts, neovascularization, collagen, bursting pressure measurements was calculated by the KolmogorovSmirnov $\mathrm{Z}$ test. It was determined that normality

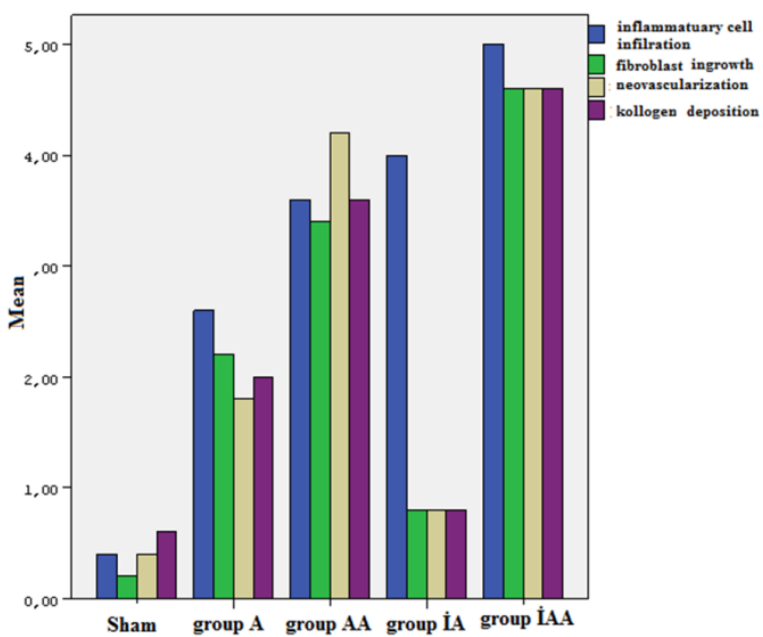

Graphic 1: The mean histological scores of the groups according to Ehrlich and Hunt numerical scale

\section{DISCUSSION}

The mean bursting pressure \pm SD of the study groups was $264 \pm 15.6$ for Group S, $148.2 \pm 8.93$ for Group A, $237.8 \pm 43.45$ for Group AA, 117.6 \pm 5.41 for Group IA, and $190.2 \pm 9.76$ for Group AIA, respectively. Anastomotic bursting pressures (ABP) were the highest in group $S$, and in a decreasing order of AA, AIA, and the lowest in group IA. The difference between $\mathrm{S}$ and AA groups was statistically insignificant in the binary comparison of the groups $(\mathrm{p}=0.222)$. A statistically significant difference was determined in the comparison of all other binary groups $(\mathrm{p}<$ 0.05) (Table 2). There were two anastomotic leakages in groups IA and AIA. was not achieved in all variables $(p<0.005)$. Accordingly, the Kruskal-Wallis $\mathrm{H}$ test was used to determine whether the mean of the specified variables differed from group to group. If the results were significant, binary comparisons with the Mann-Whitney $U$ test were made to find the differences. The results were tested at a $95 \%$ confidence level.

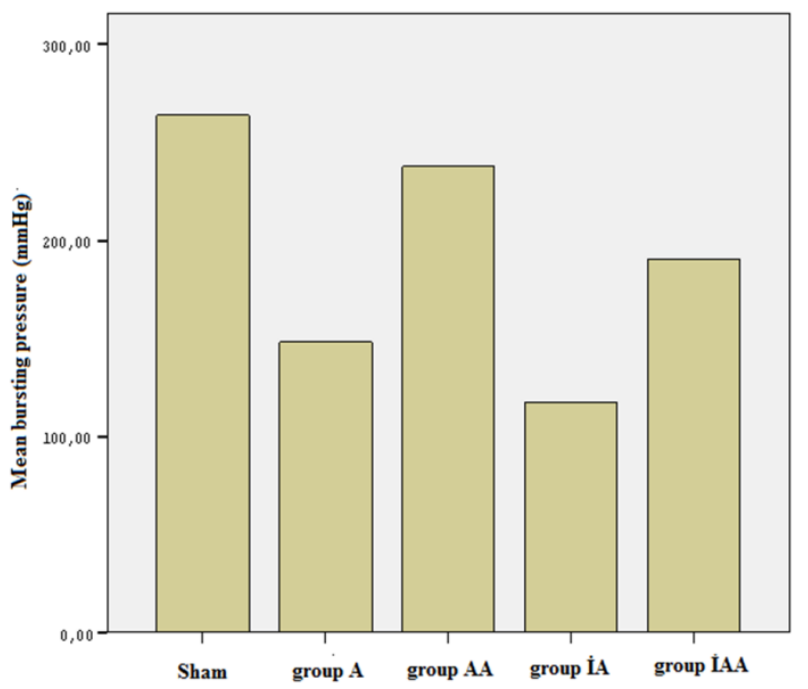

Graphic 2: Mean bursting pressure in groups(mmHg).

The Ehrlich-Hunt model measuring the score of the regeneration of the anastomotic line via inflammation, neovascularization, fibroblastic activity, and collagen formation constituted the basis of the histopathological findings. The abovementioned findings are presented in Table 2. The total score was found to be the highest in AIA group and in a decreasing order in AA, IA, A groups and the lowest in $\mathrm{S}$ group. Binary comparisons for the total scores between the groups were statistically insignificant between $\mathrm{S}$ and A groups $(\mathrm{p}=0.222)$. Other binary comparisons were statistically significant $(\mathrm{p}<0.05)$ (Table 2). 
Table 1: Ehrlich and Hunt numerical scale ${ }^{24}$

\begin{tabular}{|ll|}
\hline Histologic Grading Scale & 0 \\
No evidence & $1+$ \\
Occasional evidence & $2+$ \\
Light scattering & $3+$ \\
Abundant evidence & $4+$ \\
Confluent cells or fibers & \\
& \\
The following parameters were each assessed & \\
individually: inflammatory cell infiltration, \\
blood vessel and fibroblast ingrowth, and \\
collagen deposition
\end{tabular}

Table 2: Mean histological scoring and bursting pressure mean and standard deviation values of the groups.

\begin{tabular}{|c|c|c|c|c|c|c|c|c|c|c|c|}
\hline & \multicolumn{10}{|c|}{ GROUP } & \multirow[t]{3}{*}{$\mathbf{P}$} \\
\hline & \multicolumn{2}{|c|}{ SHAM } & \multicolumn{2}{|c|}{ Group A } & \multicolumn{2}{|c|}{ Group AA } & \multicolumn{2}{|c|}{ Group İA } & \multicolumn{2}{|c|}{ Group İAA } & \\
\hline & Mean & $\begin{array}{c}\text { Standard } \\
\text { Deviation }\end{array}$ & Mean & $\begin{array}{c}\text { Standard } \\
\text { Deviation }\end{array}$ & Mean & $\begin{array}{c}\text { Standard } \\
\text { Deviation }\end{array}$ & Mean & $\begin{array}{c}\text { Standard } \\
\text { Deviation }\end{array}$ & Mean & $\begin{array}{c}\text { Standard } \\
\text { Deviation }\end{array}$ & \\
\hline $\begin{array}{l}\text { İnflammatory cell } \\
\text { infiltration }\end{array}$ & 0,4 & 0,55 & 2,6 & 0,55 & 3,6 & 0,55 & 4 & 1,00 & 5 & 0,00 & $<0,001$ \\
\hline $\begin{array}{l}\text { Fibroblastlar } \\
\text { ingrowth }\end{array}$ & 0,2 & 0,45 & 2,2 & 0,45 & 3,4 & 0,55 & 0,8 & 0,45 & 4,6 & 0,55 & $<0,001$ \\
\hline neovascularization & 0,4 & 0,55 & 1,8 & 0,45 & 4,2 & 0,45 & 0,8 & 0,45 & 4,6 & 0,55 & $<0,001$ \\
\hline Kollogen deposition & 0,6 & 0,55 & 2 & 0,71 & 3,6 & 0,55 & 0,8 & 0,45 & 4,6 & 0,55 & $<0,001$ \\
\hline Bursting pressure & 264 & 15,60 & 148,2 & 8,93 & 237,8 & 43,45 & 117,6 & 5,41 & 190,2 & 9,76 & $<0,001$ \\
\hline
\end{tabular}

\section{CONCLUSION}

The fresh AM application is an effective treatment method used for healing colonic anastomosis in both normal and ischemic situations. These results suggest that the use of the fresh AM will shed light on the future clinical studies.

\section{REFERENCES}

1.Uludag M, Citgez B, Ozkaya O, Yetkin G, Ozcan O, Polat N, et al. Effects of amniotic membrane on the healing of primary colonic anastomoses in the cecal ligation and puncture model of secondary peritonitis in rats. Int $J$

\section{Colorectal \\ Dis. 2009; 24(5):} 67[DOI][PubMed]

$559-$

2.Kruschewski M, Rieger H, Pohlen U, Hotz HG, Buhr HJ. Risk factors for clinical anastomotic leakage and postoperative mortality in elective surgery for rectal cancer. Int $J$ Colorectal Dis. 2007; 22(8): 91927[DOI][PubMed]

3. Nursal TZ, Anarat R, Bircan S, et al. The effect of tissue adhesive, octyl-cyanoacrylate, on the healing of experimental high-risk and normal colonic anastomoses. Am J Surg.2004;187:28-32. 
4. NasirKhan MU, Abir F, Longo W, et al. Anastomotic disruption after bowel resection. World J Gastroenterol. 2006;12(16):2497-2504.

5.Zhou B, Ren J, Ding C, et al. Protection of colonic anastomosis with platelet-rich plasma gel in the open abdomen. Injury. 2014;45:864868.

6.Wenger FA, Szucsik E, Hoinoiu BF, Cimpean AM, Ionac M, Raica M. Circular anastomotic experimental fibrin sealant protection in deep colorectal anastomosis in pigs in a randomized 9-day survival study. Int $\mathbf{J}$ Colorectal Dis. 2015;30:1029-1039.

7. Cueto J, Barrientos T, Rodriguez E, et al. Further experimental studies on a biodegradable adhesive for protection of colorectal anastomosis. Arch Med Res. 2014;45: 331-336.

8. Hoare T, Yeo Y, Bellas E, Bruggeman JP, Kohane DS. Prevention of peritoneal adhesions using polymeric rheological blends. Acta Biomater. 2014;10:1187-1193

9. Kawanishi K, Yamato M, Sakiyama R, Okano T, Nitta K. Peritoneal cell sheets composed of mesothelial cells and fibroblasts prevent intra-abdominal adhesion formation in a rat model. J Tissue Eng Regen Med. 2016;10:855-866

10. Moran M, Ozmen MM, Duzgun AP et al (2007) The effect of erythropoietin on healing of obstructive vs nonobstructive left colonic anastomosis: an experimental study. World J Emerg Surg 2:13-18, doi:10.1186/1749-79222-13.

11. ling by operative lavage with nutrient solutions in experimental left-sided colonic obstruction. $\mathrm{Br}$ J Surg 82:461-464, doi:10.1002/bjs. 1800820410

12. Perju D, Târcoveanu E, Lupaşcu C (2005) Comparative experimental study of left colonic anastomoses in intestinal obstruction; the value of anastomoses protection with free peritoneal graft. Rev Med Chir Soc Med Nat Iasi 109:781786, Romanian

13. Hulkko OA, Haukipuro KA, Laitinen ST (1988) Fibrin glue protection of primary anastomosis in the obstructed left colon. An experimental study on the rat. Acta Chir Scand 154:49-52

14. Erbil Y, Calis A, Berber E et al (2000) The effect of intraoperative colonic lavage with NGnitro-L-arginine methyl ester (L-NAME) on anastomotic healing in the presence of left-sided colonic obstruction in the rat. Surg Today 30:421-425, doi:10.1007/ s005950050615

15.Bourne GL (1960) The microscopic anatomy of the human amnion and chorion. Am J Obstet Gynecol 79:1070-1073

16.Toda A, Okabe M, Yoshida T et al (2007) The potential of amniotic membrane/amnionderived cells for regeneration of various tissues. J Pharmacol Sci 105:215-228, doi:10.1254/jphs. CR0070034

17. Dua HS, Gomes JA, King AJ et al (2004) The amniotic membrane in ophthalmology. Surv Ophthalmol 49:51-77, doi:10.1016/j. survophthal.2003.10.004

18. Talmi YP, Sigler L, Inge E et al (1991) Antibacterial properties of human amniotic membranes. Placenta 12:285-288, doi:10.1016/ 0143-4004(91)90010-D

19. RinastitiM, Harijadi, SantosoAL, SosrosenoW(2006)Histological evaluation of rabbit gingival wound healing transplanted with human amniotic membrane. Int $\mathrm{J}$ Oral Maxillofac Surg 35:247- 251, doi:10.1016/j.ijom.2005.09.012

20. Tseng SC, Li DQ, Ma X et al (1999) Suppression of transforming growth factor-beta isoforms, TGF-beta receptor type II, and myofibroblast differentiation in cultured human corneal and limbal fibroblasts by amniotic membrane matrix. J Cell Physiol 179:325-335, doi:10.1002/(SICI)1097-

4652(199906)179:3<325::

AID-

JCP $10>3.0 . C O ; 2-X 21$.

21. Mermet I, Pottier N, Sainthillier JM et al (2007) Use of amniotic membranetransplantationinthetreatmentofvenou slegulcers.Wound Repair Regen 15:459-464, doi:10.1111/j.1524-475X.2007.00252.x

22. UludagM, Citgez B, Ozkaya O,Yetkin G, Ozcan O, Polat N, Isgor A. Effects of the amniotic membrane on healing of colonic anastomoses in experimental left-sided colonic obstruction Langenbecks Arch Surg. 2010 Jun;395(5):535-43. doi: 10.1007/s00423-0080443-y. Epub 2008 Dec 10. 
23. Barski D, Gerullis H, Ecke T, Varga G, Boros M, Pintelon I, Timmermans JP, Otto T. Human Amniotic Membrane Is Not Suitable for the Grafting of Colon Lesions and Prevention of Adhesions in a Xenograft Rat Model. Surg Innov. $2017 \quad$ Aug;24(4):313-320. 10.1177/1553350617709828. Epub 2017 May 26.

24. Phillips JD, Kim JS, Fonkalsrud EW, Zeng H, Dindar Z. Effects of chronic corticosteroids and vitamin $A$ on the healing of intestinal anastomoses. Am J Surg 1992;163(1):71 -7.

25. Egger B, Inglin R, Zeek J, Dirsch O, Huang Y, Büchler WM. Insulin like growth factor I and truncated keratinocyte growth factor accelerate healing of left sided colonic anastomoses. Brit J of Surg. 2001;88(1):90-8

26.Kim JC, Tseng SC. Transplantation of preserved human amniotic membrane for surface reconstruction in severely damaged rabbit corneas. Cornea. 1995;14:473-484.

27. Kesting MR, Loeffelbein DJ, Steinstraesser L, et al. Cryopreserved human amniotic membrane for soft tissue repair in rats. Ann Plast Surg. 2008;60:684-691.

28. Kesting MR, Wolff KD, Mücke T, et al. A bioartificial surgical patch from multilayered human amniotic membrane: in vivo investigations in a rat model. J Biomed Mater Res B Appl Biomater. 2009;90:930-938.

29. Uludag, M., Citgez, B., Ozkaya, O., Yetkin, G., Ozcan, O., Polat, N., \& Isgor, A. (2009). Effects of amniotic membrane on the healing of normal and high-risk colonic anastomoses in rats. International journal of colorectal disease, 24(7), 809.

30. Xing, L., Franz, M. G., Marcelo, C. L., Smith, C. A., Marshall, V. S., \& Robson, M. C. (2007). Amnion-derived multipotent progenitor cells increase gain of incisional breaking strength and decrease incidence and severity of acute wound failure. Journal of burns and wounds, 7.

31. Koizumi, N., Inatomi, T., Sotozono, C., Fullwood, N. J., Quantock, A. J., \& Kinoshita, S. (2000). Growth factor mRNA and protein in preserved human amniotic membrane. Current eye research, 20(3), 173-177. 